\title{
The Effect of Capital Structure on Abnormal Stock Returns: Evidence from Pakistan
}

\begin{abstract}
Ihsan Ullah ${ }^{1}$, Attaullah Shah ${ }^{2}$
Abstract

This study seeks an empirical investigation of the impact of financial leverage on abnormal stock returns of companies listed on the Karachi Stock Exchange. Using panel data over the period of 2005 to 2010, the study finds an existence of cross-sectional and time heterogeneity, and hence uses fixed effects regression model. The study reports an evidence of positive effect of leverage on stock returns. This evidence has several plausible explanations. Though based on varying underlying reasoning, yet agency theory, trade-off theory, bank debt signaling model, and management timing hypothesis predict favorable impact of leverage on stock returns. Therefore, the findings of this study are consistent with the predictions of all these theories.
\end{abstract}

Keywords: financial leverage, abnormal stock returns, capital structure.

\section{Introduction}

Since shareholders are the owners of a corporation, the financial objective of a firm should be shareholders' wealth maximization. An achievement of this objective is analogous to enhancing shares prices. Thus, managers' decisions including financing decisions (that affect capital structure) should be aimed at increasing shares prices. The important question that arises is: Does a change in capital structure affect shares prices, and create value for a firm? Current research attempts to answer this question by finding the impact of financial leverage on stock returns given the peculiar conditions of Pakistan.

The effect of capital structure remained ambiguous until the seminal contribution emerged from Modigliani and Miller (Henceforth called MM) in 1958. Their irrelevance theorem, based on unrealistic and simplifying assumptions, emphasizes irrelevance of a firm's value in response to changes in capital structure. In other words, in the absence of market frictions, managers cannot create value just by varying a mix of debt and equity. Following MM, a string of theoretical literature has emerged. Trade-off theory, pecking order theory, agency theory along with bank debt signaling

1. Ihsan Ullah is a PhD scholar at the Institute of Management Sciences and an Assistant Professor at FAST, National University of Computer and Emerging Sciences, Peshawar, Pakistan. E-mail: ihsan. ullah@nu.edu.pk

2. Dr. Attaullah Shah is an Assistant Professor at the Institute of Management Sciences, Peshawar, Pakistan.E-mail: attaullah.shah@imsciences.edu.pk 
model, and management timing hypothesis are regarded as the most prominent ones. Trade-off theory recognizes trade-off between bankruptcy costs and tax-shield associated with debt financing. It favors the existence of an optimal capital structure that maximizes a firm value. Pecking-order theory, mainly contributed by Myers (1984) and Myers and Majluf (1984) considers retained earnings as the cheapest source of finance, followed by debt and finally external equity as the most expensive component. Based on asymmetric information, the theory highlights issuing securities to raise external capital signals out a lower profitability to investors than what they had expected. Being rational in their decisions, investors adjust the discount rate for the firm upward since they now require a higher return on their capital. The obvious consequence is the drop in a share price. Agency theory predicts a positive effect of debt financing on a share price since it disciplines managers by eliminating the conflicts of interest between shareholders and managers. Bank debt signaling model emphasizes the role of banks as vigilant lenders carrying more reliable and inside information about a business. Thus, securing a bank loan is received as positive news about financial health and future prospects of the business by market participants followed by a favorable outcome for stock returns. Finally, management timing hypothesis states that issuing debt signals to investors the management's perception about the stock being currently underpriced. It further leads to higher aggregate demand for the stock, putting upward pressure on the share price finally resulting into higher stock returns. This research effort centers on the empirical examination of the predictions of the above mentioned theories in particular context of Pakistan.

As evident from the preceding discussion, the theories on the topic assume conflicting positions. For instance, the implication of MM's irrelevance proposition for managers is to choose a mix of debt and equity randomly. On the contrary, agency theory, bank debt signaling model and management timing hypothesis suggest preferring debt financing over equity financing. Similarly, trade-off theory also encourages issuance of debt until the optimal capital structure has arrived. Finally, unlike the above mentioned theories, pecking order theory favors use of internal equity over debt financing. The contradictory implications leave managers in a fix. Unfortunately, the current state of the empirical research has also not been a source of great guidance and comfort for the managers. To evaluate an effect of financial leverage on value of a firm, empirical researchers have adopted diverse methodologies. Usually conforming to regression analysis, the empirical researches diverge on number of other issues. The disagreement appears even in the construction of the fundamental variables, financial leverage and stock returns. With respect to leverage, two broad measures are used, book leverage and market leverage. Similarly, a variety of stock returns are employed. These include expected stock returns, contemporaneous stock returns, and risk-adjusted stock returns and so on. Such diverse measures of leverage and 
returns render difficulty in reaching unanimous conclusion on the implications of leverage for value of a firm. In search of the more plausible explanations, the recent empirical effort also encompasses additional factors such as industrial classification of firms and type of debt being issued. It, however, usually disregards the existence of cross-sectional and/or time heterogeneity. To account for this shortcoming, the model developed in this study specifically tests for fixed and random effects. A book measure of leverage has been employed for two reasons. First, debt is not publicly traded in Pakistan. Second, book value of debt represents the true burden on corporate cash flows. Finally, the model developed in this article only caters for the effect of leverage on abnormal stock returns. It does not, however, classify the abnormal stock returns further into positive or negatives ones.

The objective of the study is to find out the effects of financial leverage on abnormal stock returns using panel data for non-financial firms listed on the Karachi Stock Exchange over the period 2005 to 2010. Most of the available evidence unfolds that empirical investigation of abnormal stock returns in relation with leverage is still largely an unexplored area in Pakistan. The contribution of the study comes in many folds as discussed in detail in the last section of the article. It offers new empirical evidence on abnormal stock returns which currently seems to be largely unexplored area in Pakistan. Also, the research carries important implications for corporate managers and investors since it endeavors to undertake the deviation of actual returns from their expected ones due to financial leverage. Finally, the research adds to the empirical validity of the prominent theories on the topic.

\section{Literature Review}

This section presents a review of literature in a thematic fashion. The first aspect to explore is the value relevance of financing decisions irrespective of positive or negative effect, followed by if the type of debt being issued has any bearing. Next, a short glimpse of private debt placement and industry effect is given. Finally, a brief review of studies from Pakistan follows. The overall motivation is to discuss the empirical validity of the theories mentioned above which predict contradictory effects of a change in capital structure on the firm's value and shareholders' wealth. The review of empirical literature reveals that none of the theories serves as one-size-fitfor-all. A prediction of one theory may be valid in one case but empirically incorrect in the other. Thus, understanding the overall context, characteristics of an issue of debt and characteristics of a firm itself are mandatory for the deep insight into the puzzle of capital structure.

Empirical research has focused on problem of capital structure from different angles by employing different measures of leverage and stock returns. Nevertheless, 
the first logical question one should ask: Is capital structure value relevant at all? The answer to this question is a strong yes coming from substantial empirical evidence. For instance Bhandari (1988) sought an effect of financial leverage on expected common stock returns by employing US data from 1948 to 1979. The market leverage appeared to carry significant and positive relationship with the expected stock returns. Increasing leverage would bring an additional risk to common shareholders and thus they would require higher return as a compensation for bearing extra risk due to leverage. Fama and French (1992) expanded the argument by noting down that book-to-market $(\mathrm{BE} / \mathrm{ME})$ equity subsumed leverage effect. It stated that the relevant leverage measure that explained the cross-section of stock returns was the difference between the book leverage and market leverage, and the $\mathrm{BE} / \mathrm{ME}$ ratio captured that difference. Thus, the study concluded that a parsimonious model to explain cross-section of stock returns should include only size and $\mathrm{BE} / \mathrm{ME}$ ratio since beta had no relation with stock returns and the leverage and $\mathrm{P} / \mathrm{E}$ ratios appeared to be redundant. It is important to realize that the study did not discard leverage effect but to exclude it from the model since its effect was already captured by another stronger variable (BE/ME). This conclusion of $\mathrm{BE} / \mathrm{ME}$ subsuming leverage effect, however, is not unanimous since many other empirical studies have used $\mathrm{BE} / \mathrm{ME}$ ratio as a control variable with leverage and yet the evidence obtained indicates towards an existence of separate statistically significant leverage effect. Accounting for risk, Dimitrov and Jain (2005) used risk-adjusted contemporaneous stock returns and risk-adjusted future stock returns by employing data on stocks listed on NYSE, AMEX and NASDAQ from 1973 to 2001. The authors found that a change in leverage is statistically significantly value relevant for a firm. To be more precise, the authors found negative effect of leverage on risk-adjusted contemporaneous as well as on future stock returns. In the authors' opinion issuing debt larger than expected (after controlling for debt required for normal growth and mergers and acquisitions) revealed under economic performance /operating performance of a firm to market participants which caused stock prices to depress. Creating a different measure of leverage, Bradshaw, Richardson, and Sloan (2006) used aggregated information from financial statements to construct their own measure of external financing and attempted to ration its effect on future stock returns. The study found the evidence of negative relation between the two variables. Upon further analysis, it was discovered that over optimism in sell side analyst's forecasts was positively related to their measure of net external financing. In other words, analysts and investors had over expectations about the future earnings prospects of firms raising capital through new external financing and when those expectations collapsed the stock prices declined. The same over optimism was also noted by Chang, Cheng, and Tsai (2008) in analysts' forecasts for firm announcing bank loans. Expanding the evidence beyond US-market, Ho, Strange, and Piesse (2006) conducted a comprehensive study employing data from Hong Kong market. The study found 
beta, size, and book-to-market effect as risk factors that were rewarded by the market conditional upon the market situation. The study, however, missed important variable, financial leverage, which can add up to the risk and hence may explain heterogeneity in stock returns at least in part. In order to overcome this shortcoming, Ho, Strange, and Piesse (2008) conducted another study which accounted for financial leverage along with the above mentioned variables. The study added new dimension to the literature by finding the evidence that market leverage is considered as a risk factor and hence priced by the market conditional upon market situation. Using abnormal stock returns, Adami, Gough, Muradoglu, and Sivaprasad (2010) unfolded statistically significant negative relation between leverage and abnormal stock returns under all models employed by the study, contributing to robustness of the finding. The same negative result was reached by Cai and Zhang (2011). The authors noticed drop in stock returns in response to increase in leverage for both equal and value-weighted portfolios. To sum up, regardless of negative or positive effect of financial leverage overwhelming majority of researchers found it as value relevant. This is not evident only from the above mentioned studies but also one can refer to many more credible researches such as Simerly and Li (2000) and Zeitun and Tian (2007).

In the light of above quoted substantial empirical evidence, it is easy for one to infer that leverage, irrespective of its positive or negative outcome, does affect a firm's value and hence shareholders' wealth. The next logical question one may ask: Does it matter for a type of a debt security to influence stock returns in different/opposite direction or with varying magnitude? Again, the answer is equally strong yes. Many of the researchers have found that it is convertible debt that prompts severe negative reaction from market participants. This is evident from (Eckbo, 1985). Employing US data, the study found negative relation between leverage and stock returns for convertible debt. For straight bonds, irrespective of their risk level, no such relationship was observed with the exception of subsample of mortgages. Incorporating the stated reason for debt financing along with type of debt financing, Mikkelson and Partch (1986) analyzed the effect of securities offerings on stock returns. The authors discovered that the stock price response was more profoundly negative to issuance of common stock when offered to refinance debt as compared to those which were intended for capital expenditures. In other words, the stated reason for the offering appeared to be statistically influential. More importantly, the authors found evidence that the type of security had the most effect on stock returns. Convertible debt and common stock offerings had more negative effect on stock prices conforming to pecking order theory and notion that such offerings signal to the market that the securities are currently overpriced. On the contrary, the response to straight debt offerings was found to be statistically insignificant. Almost the same result was reached at by Dichev and Piotroski (1998). The study concluded that straight debt issues signaled no information to the 
market. The authors further observed that large convertible debt issuers in quintile 5 underperformed the market and the small issuers of convertible debt (quintile 1) on the magnitude of 50-70 percent and the difference was statistically significant. Such an adverse reaction to convertible bonds was due to the market perception about deteriorating future profitability of the issuing firms since convertible bonds bear a risk of being converted into common shares and the commons have to carry the loss in operating profitability. The evidence obtained outside US is not necessarily in agreement with the US evidence. For instance, Roon and Veld (1995) using data from the Dutch market found positive cumulated annual abnormal return of .53\% for issuance of convertible bonds. In the authors' opinion the favorable reaction to announcement of convertible bonds was due to accompanying of other good news packaged with the announcement that prompted positive reaction from investors. Ho and Abhyankar (2002) provided evidence from UK. The researchers found underperformance of firms after three years of issuance of convertible preferred shares and convertible bonds as consistent with the US evidence. Díaz, Martell, and Ramírez (2008) shed more light on the issue and added new perspective to it by considering the negative reaction to $\mathrm{CBs}$ in the context of agency problems. They found that market reacted more negatively to convertible bonds issuance by the firms that had severe agency problems. Also, such firms were found to be more likely to force conversion of their in-the-money convertible bonds. Overall, agency problems appeared to have role in determining the magnitude of negative reaction to convertible bonds issuance.

Researchers have also looked into other aspects of capital structure such as private debt placements, and industry effects. The popular view that private debt placements reduce information asymmetry and also lenders have incentive to monitor and therefore such arrangements lead to better stock and operating performance has been proved wrong (Liu and Yang, 2011). Industry effects have been found to be statistically significant ( See, e.g., Bou \& Satorra, 2006; Goddard, Tavakoli, \& Wilson, 2009; Amato \& Wilder, 2004; Muradog ${ }^{`}$ lu \& Sivaprasad, 2012).

Most of the empirical literature in Pakistan focuses on measures of firm's performance other than abnormal stock returns. These measures usually include return on assets (RoA), return on equity (RoE), and earnings per share (EPS). For instance, (Khan, 2012) focuses on 36 companies from engineering sector for the period 2003 2009. The study reported negative relationship between leverage and RoA. The similar negative effect is also reported by Saeed and Badar (2013) and Amara and Aziz (2014) concentrating on sugar and food sectors, respectively. It is worth mentioning that these studies employed small samples and estimated only pooled regression disregarding any differences amongst firms and years. Unlike the above mentioned studies, Rafique (2011) evaluated an effect of performance (profitability) on capital 
structure. The study could not find any statistical significant effect, implying that one does not have to worry about reverse causality when examining effect of capital structure on performance.

It is important to mention that based on the overwhelming evidence reported above, the study expects leverage to appear as statistically significant variable in explaining cross-section of abnormal returns for firms operating in Pakistan.

\section{Methodology}

The research begins with a random selection of 230 firms listed on Karachi Stock Exchange (KSE). Financial statements data is taken from the State Bank of Pakistan publications "Balance Sheet Analysis of Joint Stock Companies Listed on The Karachi Stock Exchange". Share price data is collected from Karachi Stock Exchange (KSE) website. Since financial companies' balance sheets demonstrate fundamental differences with those of non-financial companies, therefore, 46 financial firms are dropped out. From the remaining sample, 99 firms are excluded since they do not meet the sample construction criterion discussed below.

The computation of Cumulated Annual Abnormal Returns (henceforth called CAARs, and discussed further later in this section) requires the availability of end of the month share prices ideally for all 12 months. If they are available for less than 12 months, then the CAAR is calculated as the average of abnormal returns for the available months. Also, end of year leverage is required to be non-negative for firm year observation to enter the sample. Moreover, for a firm to be included in the sample, it must have CAAR and leverage available for at least two years out of the total six years from 2005 to 2010. The final number of the firms remaining in the sample ends up as 85 . Out of these 85 firms, all 6 years data is available for 70 firms, 5 years data is available for 7 firms, 4 years data is available for 3 firms, and minimum required data of 2 years is available for 5 firms.

CAAR for each firm (i) in each year $(\mathrm{t})$ is calculated as

$$
\mathrm{CAAR}_{i, t}=\sum_{\mathrm{t}=1}^{12} \mathrm{AR}_{\mathrm{i}, \mathrm{t}}
$$

Where AR is the abnormal return for firm (i) in year ( $(t)$ calculated as

$$
A R_{i, t}=R_{i, t}-E(R)_{i, t}
$$

Where $\mathrm{R}_{\mathrm{i}, \mathrm{t}}$ is the monthly return of firm (i) in month $(\mathrm{t})$ and $\mathrm{E}(\mathrm{R})_{i, t}$ is the monthly expected return for the same firm (i) in same month ( $t$ ) calculated using Capital Asset Pricing Model (CAPM) where KSE-100 Index returns are used as a proxy for monthly market returns. Leverage is calculated for each firm as the ratio of total debt divided 
by sum of total liabilities and shareholders' equity. Since firms in Pakistan heavily rely on bank loans rather than other modes of financing (Shah, 2007), thus the question of using book or market leverage becomes insignificant. Also, book leverage represents relevant and direct cash flows for a firm, thus the study uses book leverage as a measure of leverage. The review of empirical literature in the earlier section unveiled determinants of stock returns other than leverage (e.g., Fama \& French, 1992; Muradog `lu \& Sivaprasad, 2012). These other explanatory variables mainly include size, market-to-book ratio (MTB), price-to-earnings ratio (PE), and Market Risk. Based on their relevance, they must be included in the regression model to avoid omitted relevant variable bias (Koop, 2005). MTB is the ratio of closing market price per share divided by book value of equity per share. PE is the ratio of closing annual share price divided by earnings per share. Size is the natural log of market capitalization of a firm which is equal to number of shares outstanding times annual closing share price. Risk represents market risk of a firm taken as an average of 12 monthly time variant betas calculated using data from previous year through a rolling window of 60 observations. Having constructed the entire set of the above mentioned dependent and independent variables, following pooled regression equation is initially estimated.

$$
\mathrm{CAAR}_{i, t}=\beta_{0}+\beta_{1} \text { Leverage }_{i, t}+\beta_{2} \text { MTB }_{i, t}+\beta_{3} \mathrm{PE}_{i, t}+\beta_{4} \text { Risk }_{i, t}+\beta_{5} \text { Size }_{i, t}+\mu_{i, t}
$$

This model is highly restricted in a sense that it assumes no cross-sectional or time heterogeneity. This assumption is highly bold and may lead to making wildly wrong inferences. Thus, an attempt is made to investigate if the heterogeneity exists either across space or time. Finally, the study settles down for the following equation where both cross-sectional and time variation is allowed by using Fixed Effect or Least-Square Dummy Variable (LSDV) Regression Model. The selection of this model is guided by the results obtained from Redundant Fixed Effect test and Hausman test conducted to check the existence of fixed and random effects, respectively.

$$
\mathrm{CAAR}_{i, t}=\alpha_{0}+\beta_{1} \text { Leverage }_{i, t}+\sum_{y=2}^{n} \beta_{\mathrm{y}} Z_{\mathrm{y}, \mathrm{t}}+\mu_{\mathrm{i}, \mathrm{t}}
$$

where,

$\mathrm{CAAR}_{i . t}$ is the dependent variable and computed as defined in Equation 1,

$\alpha_{i}$ represents firm specific intercept,

Leverage $_{i, t}$ is the main independent variable of the study, and

$Z_{y, t}$ includes the vector of control variables $(M T B, P E$, Risk, Size, Firm and Year specific dummies) 
The first dummy and the second dummy variables allow for cross-sectional and time heterogeneity. The precise construction of all the above mentioned variables has been provided in the previous discussion of the same section. All the models have been estimated using ordinary least square (OLS) method.

\section{Empirical Results and Analysis}

To find out the impact of leverage on CAARs, the study starts preliminary investigation by presenting descriptive statistics in the following table with primary focus on CAARs and leverage.

Table 1: Descriptive Statistics

\begin{tabular}{|c|c|c|c|c|c|c|}
\hline & CAAR & $\begin{array}{c}\text { LEVER- } \\
\text { AGE }\end{array}$ & MTB & PE & RISK & SIZE \\
\hline Mean & -0.1606 & 0.5173 & 1.4581 & 4.2879 & 0.7331 & 21.970 \\
\hline Median & -0.1554 & 0.5458 & 1.0527 & 5.8609 & 0.6952 & 22.285 \\
\hline Maximum & 1.4862 & 1.2809 & 80.550 & 273.94 & 12.945 & 27.322 \\
\hline Minimum & -1.6119 & 0.0314 & -148.98 & -1030.6 & -0.7651 & 15.142 \\
\hline Std. Dev. & 0.4700 & 0.2348 & 9.4510 & 60.524 & 0.7665 & 2.2267 \\
\hline
\end{tabular}

This table presents descriptive statistics of the sample employed in this study. The sample consists of 85 firms and covers period from 2005-2010. Stock returns (CAAR) are computed as defined in Equation 1. Leverage is computed as a ratio of total debt to total financing of a firm. Market-to-Book ratio (MTB) is the ratio of closing market price per share divided by book value of equity per share. Price-to-earning (PE) represents ratio of closing share price to earnings per share. Risk is the market risk based on the computation of average of 12 monthly time variant betas using data through a rolling window of 60 observations. Size represents natural log of market capitalization of a firm which is a product of number of shares outstanding and closing annual share price.

As evident from the table an average firm in the sample has negative CAAR of $16.06 \%$. The maximum and minimum values of CAAR in the sample are $148.6 \%$ and $-161.1 \%$ respectively, yet they cannot be classified as outliers since they do not deviate from the mean by 4 standard deviations (Mason, Lind \& Marchal, 1999). The distribution of the dependent variable (CAAR) demonstrates a considerable dispersion of $47 \%$. The table also reports that a typical firm in the sample finances its assets with $51.73 \%$ capital raised through debt. Some of the firms are highly levered up to the extent of $128 \%$, while others are heavily relying on equity financing up to the level of about $97 \%$. Certainly, individual leverage values are less scattered around their mean as reflected by the standard deviation of only $23 \%$ (as compared to distribution of CAARs).

To begin regression analysis, Equation 3 is estimated with specific interest in testing the following hypothesis: 
$H_{0}$ : Financial Leverage has no effect on stock returns. That is, $\beta_{1}=0$.

$H_{1}$ : Financial Leverage has no effect on stock returns. That is, $\beta_{1} \neq 0$.

The results from this regression (Equation 3) are reported in Table 2.

As evident from Table 2, the regression output reveals negative effect of leverage on CAARs though the effect is statistically insignificant even at $10 \%$ significance level. It is, however, very important to mention that drawing inferences from this model could be widely misleading since the model is highly restricted in a sense that it does not allow for any type of fixed or random effects. The underlying assumption for this model is highly unrealistic if fixed or random effects exist across cross-sectional units (firms) and/or time (years) due to firms specific factors that do not change overtime such as differences in managerial style or philosophy (fixed effects) or time variant effects such as technological changes, government policies (random effects). To avoid the risk of making such bold assumption, it is indispensible to check for fixed

Table 2: Results from Pooled Regression

\begin{tabular}{|c|c|c|c|c|}
\hline Variable & Coefficient & Std. Error & t-Statistic & Prob. \\
\hline C & -1.2691 & 0.2547 & -4.9808 & 0.0000 \\
\hline LEVERAGE & -0.0608 & 0.1025 & -0.5934 & 0.5532 \\
\hline MTB & 0.0035 & 0.0025 & 1.3903 & 0.1653 \\
\hline PE & -0.0001 & 0.0003 & -0.4016 & 0.6882 \\
\hline RISK & -0.0780 & 0.0318 & -2.4470 & 0.0149 \\
\hline SIZE & 0.0542 & 0.0111 & 4.8648 & 0.0000 \\
\hline & & & & \\
\hline R-squared & 0.0834 & & & \\
\hline $\begin{array}{c}\text { Adjusted } \\
\text { R-squared }\end{array}$ & 0.0707 & & & \\
\hline F-statistic & 6.5749 & & & \\
\hline Prob(F-statistic) & 0.000007 & & & \\
\hline
\end{tabular}

This table presents results from pooled regression as defined in Equation 3 without allowing cross-sectional or time heterogeneity. The regression is estimated using ordinary least square (OLS) method. The sample consists of 85 firms and covers period from 2005-2010. Stock returns (CAAR) are computed as defined in Equation 1. Leverage is computed as a ratio of total debt to total financing of a firm. Market-to-Book ratio (MTB) is the ratio of closing market price per share divided by book value of equity per share. Price-to-earning (PE) represents ratio of closing share price to earnings per share. Risk is the market risk based on the computation of average of 12 monthly time variant betas using data through a rolling window of 60 observations. Size represents natural log of market capitalization of a firm which is a product of number of shares outstanding and closing annual share price. Coefficients, standard errors, t-statistics, and probability values are reported for each explanatory variable in a separate column. 
and random effects. To test for the former, redundant fixed effect test is employed. More specifically, the following three hypotheses are tested under F and Chi-Square versions of the test:

First hypothesis:

$H_{0}$ : The cross - sectional fixed effects do not exist.

$H_{1}:$ The cross - sectional fixed effects exist.

Second hypothesis:

$H_{0}$ : Period fixed effects do not exist.

$H_{1}$ : Period fixed effects exist.

Third hypothesis:

$H_{0}:$ The cross - sectional and Period fixed effects do not exist.

$H_{1}$ : The cross - sectional and Period fixed effects exist.

The test results are reported in Table 3

As evident from the table, all the null hypotheses can be safely rejected under both versions concluding that there are both cross-sectional and period fixed effects and hence results from the pooled regression (Table 2) cannot be relied upon. Having checked the fixed effects, it is also important to test the random effects in order to finalize the regression model. For this purpose, Hausman test is conducted which test the following hypothesis:

Table 3: Redundant Fixed Effects Tests

\begin{tabular}{|c|c|c|c|}
\hline Effects Test & Statistic & d.f. & Prob. \\
\hline Cross-section F & 1.4727 & $(83,274)$ & 0.0111 \\
\hline Cross-section Chi-square & 135.3817 & 83 & 0.0003 \\
\hline Period F & 3.3838 & $(4,274)$ & 0.0101 \\
\hline Period Chi-square & 17.6961 & 4 & 0.0014 \\
\hline Cross-Section/Period F & 1.6868 & $(87,274)$ & 0.0008 \\
\hline Cross-Section/Period Chi-square & 157.4167 & 87 & 0.0000 \\
\hline
\end{tabular}

This table reports results for the test conducted to examine the existence of cross-sectional and/or period fixed effects. The test has three parts. The first one examines only cross-sectional fixed effects. The second one examines only period fixed effects. The third one evaluates both cross-sectional and period fixed effects. For each part, the test employs $\mathrm{F}$ and Chi-Square as test-statistics. 
$H_{0}:$ Random effects exits.

$H_{1}$ : Random effects do not exits.

The test results are reported in Table 4

The table shows that the p-value is zero up to four decimal places, thus the test rejects the existence of random effects (As a precaution, the study also runs regression of random effect model, which results are not reported here for brevity. It is, however, clear from the results that they are not qualitatively different from the results obtained from the pooled regression model (eq. 3), implying non-existence of random effects).

Table 4: Correlated Random Effects - Hausman Test

\begin{tabular}{|c|c|c|c|}
\hline Test Summary & Chi-Sq. Statistic & Chi-Sq. d.f. & Prob. \\
\hline Cross-section random & 47.3494 & 5 & 0.0000 \\
\hline
\end{tabular}

This table presents results for the test conducted to examine cross-sectional random effects. The test uses Chi-Square as a test statistic.

We eventually selected fixed effect/ Least Square Dummy Variable Regression Model (Equation 4) with main focus on testing the following hypothesis. That is,

$H_{0}$ : Finacial Leverage has no effect on the stock returns. That is, $\beta_{1}=0$.

H1: Finacial Leverage has an effect on the stock returns. That is, $\beta_{1} \neq 0$.

The results from this regression model appear in Table 5.

Before the study discusses the regression results from Table 5 about leverage, it is important to note that R-Squared value has remarkably enhanced, implying that the pooled regression model (Equation 3) contained specification error since the number of explanatory variables has remained same. Also, the p-value associated with F-statistic is worth considering, suggesting that not all coefficients are equal to zero at the same time in the population. After correcting for the model specification, leverage has turned out to be statistically significant. Also, its coefficient has substantially improved from only 0.06 to magnificent 0.74 . The sign has also changed from negative to positive. Thus, the inferences would have been widely wrong had they been drawn upon the pooled regression (Equation 3) since it assumed no space and time heterogeneity. Finally, the conclusion of the rigorous regression analysis is the significant positive effect of leverage on abnormal stock returns for firms operating in Pakistan. To be more precise, both variables are positively correlated with each other. In other words, increasing leverage by 1 percent causes an increase of 0.74 percent in abnormal stock returns keeping other variables constant of course. 
Table 5: Results from Fixed Effect Model.

\begin{tabular}{|c|c|c|c|c|}
\hline \multicolumn{1}{|c|}{ Variable } & Coefficient & Std. Error & t-Statistic & Prob. \\
\hline C & -7.5168 & 1.3207 & -5.6913 & 0.0000 \\
\hline LEVERAGE & 0.7442 & 0.2744 & 2.7115 & 0.0071 \\
\hline MTB & 0.0003 & 0.0030 & 0.1163 & 0.9074 \\
\hline PE & 0.0001 & 0.0004 & 0.3632 & 0.7167 \\
\hline RISK & 0.0029 & 0.0381 & 0.0778 & 0.9380 \\
\hline SIZE & 0.3171 & 0.0583 & 5.4351 & 0.0000 \\
\hline Effects Specification & & & & \\
\hline $\begin{array}{l}\text { Cross-section fixed (dum- } \\
\text { my variables) }\end{array}$ & & & & \\
\hline $\begin{array}{l}\text { Period fixed (dummy } \\
\text { variables) }\end{array}$ & & & & \\
\hline R-squared & 0.4031 & & & \\
\hline Adjusted R-squared & 0.2027 & & & \\
\hline F-statistic & 2.0116 & & & \\
\hline Prob(F-statistic) & 0.000007 & & & \\
\hline
\end{tabular}

This table presents results from fixed effect/least square dummy variable regression model as defined in Equation 4. The model makes allowance for cross-sectional and time heterogeneity and is estimated using ordinary least square (OLS) method. The sample consists of 85 firms and covers period from 2005-2010. Stock returns (CAAR) are computed as defined in Equation 1. Leverage is computed as a ratio of total debt to total financing of a firm. Market-to-Book ratio (MTB) is the ratio of closing market price per share divided by book value of equity per share. Price-to-earning (PE) represents ratio of closing share price to earnings per share. Risk is the market risk based on the computation of average of 12 monthly time variant betas using data through a rolling window of 60 observations. Size represents natural $\log$ of market capitalization of a firm which is a product of number of shares outstanding and closing annual share price. Coefficients, standard errors, t-statistics, and probability values are reported for each explanatory variable in a separate column.

The positive relation between returns and leverage has several plausible explanations. First, it is important to recognize that many studies conducted on foreign data particularly on US and UK data report negative relation between the two variables (Eckbo, 1986; Dichev \& Piotroski, 1999; Dimitrov \& Jain, 2006; Bradshaw et al., 2006; Adami et al., 2010). Why do the results obtained in this study fail to portray the negative relationship? The answer lies in the fact that these studies report negative response from market participants in reaction to issuance of convertible debt. The response to straight debt issuance usually remains insignificant. An adverse reaction to convertible debt is usually found due to market perception about deteriorating future profitability of issuing firms since convertible bonds bear a risk of being converted into common shares and commons have to carry loss in operating profitability (Dichev \& Piotroski, 1998). Thus, one should not expect to reveal negative relation 
between leverage and returns in Pakistan since there is a rare reliance on any type of debt (including convertible debt) except bank loans in the country. Second, there are very limited channels in the country to raise debt capital and the most commonly used source of raising debt capital is bank loans for many firms (Shah, 2007). Bank debt signaling models suggest a positive reaction from the market in response to bank debt announcements since bankers are viewed as important transmitters of information to the capital market (Hull \& Moellenberndt, 1994). The underlying notion is an ability of banks, being lenders, to have more precise and inside information about a business. Thus, issuance of a bank debt signals out to a market positive news since it reflects a bank's favorable opinion on future prospects and financial health of a business. Based on the prediction of bank debt signaling models, one should expect a positive relation between leverage and returns, which is consistent with the finding of this research article. Third, the finding lends support to trade-off theory which recognizes positive stock price response to increase in leverage since debt provides tax shelter due to interest payments being tax deductible. However, this relationship is not linear and beyond the optimal point market reaction is adverse for acquisition of more debt. The finding apparently suggests that the optimal point has not yet arrived for many firms in Pakistan and that is why market responds positively when more debt is acquired. Fourth, the evidence is consistent with agency theory which emphasizes using debt disciplines managers, prevents unproductive expenditures and forbid undertaking risky investments at the expense of shareholders. In other words, leverage minimizes agency costs by aligning interests of managers with those of shareholders which should consequently be rewarded by the market. Fifth, the finding is also in accordance with the prediction of management timing hypothesis which suggests that managers will sell equity rather than debt if they believe that current market of the firm's shares is greater than the intrinsic value, that is, the shares are currently overpriced. By same token, they will sell debt rather than equity if they believe that shares are currently underpriced. Thus, issuing debt transmits important information about the management's perception of the shares being currently underpriced, consequently stimulating a favorable reaction from the market. The last plausible possible explanation is the availability of growth prospects in Pakistan. Increasing leverage indicates utilization of the growth opportunities which consequently leads to higher expected future cash flows. This optimism prompts a favorable response from investors resulting into positive effect of financial leverage on stock returns.

Though main focus of the study is on leverage, yet discussion of the other explanatory variables is warranted. As evident from the regression results in Table 5, size has appeared statistically significant even at the significance level of 1 percent. Thus, this finding can be generalized to the entire population of listed non-financial firms operating in Pakistan. The positive coefficient of 0.317 indicates that increase in 
size leads to increase in stock returns. In other words, the larger the firm, the higher its stock returns. Overall the finding suggests that larger firms are more resourceful as compared to their smaller counterparts, giving them a competitive advantage. Consequently, they can produce larger stock returns for their shareholders. It is also worth mentioning that market-to-book ratio, price-to-earnings ratio, and risk have been found statistically insignificant event at 10 percent as evident from their larger p-values and smaller t-statistics. Thus, the coefficients obtained for these variables are just by chance and limited only to this sample. The change in sample from the same population will result into different coefficients, therefore, they are unreliable and cannot be generalized to the entire population.

\section{Conclusion}

The empirical investigation of financial leverage in determining abnormal stock returns is warranted in Pakistan since it appears to be still largely an unexplored area in the country. The research covers six years from 2005 to 2010 and the sample includes 85 non-financial companies listed on KSE. Following the result from Fixed Effect Redundant test and Hausman test, Fixed Effects Model or Least-Square Dummy Variable Regression Model is employed to analyze the panel data. The evidence found in this study suggests that leverage has statistically significant positive effect on returns. The evidence has several plausible explanations. As discussed in detail in the previous section, the finding is consistent with the predictions of agency theory, trade off theory, management timing hypothesis, and bank debt signaling model. Moreover, increasing leverage possibly causes investors to form bright view of the forthcoming cash flows, thereby resulting into enhanced stock returns. The study could not find a negative effect of leverage on returns unlike many studies conducted in the developed world because of limited reliance on convertible debt in Pakistan (Shah, 2007).

The contribution of the study comes in many folds. Firstly, the existing evidence on abnormal stock returns appears to be largely scarce in Pakistan. Secondly, most studies conducted to investigate the effect of leverage on stock returns ignore the possibility of differences amongst firms and/or years. This study endeavors to add to the indigenous empirical literature by focusing on abnormal stock returns and permitting cross-sectional and time heterogeneity. As evident from the comparison of regression results reported in Table 2 and 5, the allowance for cross-sectional and time differences removed the specification error and improved the explanatory power of the model from mere 8.3 percent to 40.3 percent. In nut shell, based on better specification of the model, the study contributes naïve and valuable input to the existing empirical literature in Pakistan. Thirdly, the positive effect of leverage on stock returns carries important implications for managers, investors and the government. For managers, 
it is not only the investment decisions that create value for the firm. The financing decisions are equally important. The finding suggests that increasing debt in the capital structure maximizes wealth of shareholders. Investors also need to be more attracted to firms with considerable reliance on debt since these are the firms found capable of generating higher stock returns. For the benefit of firms and shareholders, the government of Pakistan ought to encourage bank borrowings and develop other debt market mechanisms. The current reliance on bank borrowings needs to be expanded along with opening up new channels for debt financing. Finally, the study tested for empirical validity of different capital structure theories. As discussed in the previous section, the finding lends empirical support to agency theory, management timing hypothesis, bank debt signaling model, and trade-off theory using indigenous data for firms operating in the country.

Despite of the contributions mentioned above, the study has its own short comings. Of particular interest to one should be some excluded factors from the model which are peculiar only to Pakistan and could be a primary focus of research in future. These factors include terrorism, other type of militant activities, and energy crisis. The next limitation is subject to data availability in Pakistan. For instance, due to lack of data available on dividends, the computed stock returns are based only on closing share prices. Finally, the heavy reliance on bank debt in Pakistan (Shah, 2007) does not permit to gain insight into other types of debt financing.

\section{References}

Adami, R., Gough, O., Muradoglu, G., \& Sivaprasad, S. (2010). The leverage effect on stock returns. European Financial Management, Portugal.

Amara., \& Aziz, B. (2014). Impact of capital structure on firm performance: Analysis of food sector listed on Karachi Stock Exchange. International Journal of Multidisciplinary Consortium, 1(1), 1-11.

Amato, L. H., \& Wilder, R. P. (2004). Global competition and global markets: some empirical results. International Business Review, 13(3), 401-416.

Bhandari, L. C. (1988). Debt/equity ratio and expected common stock returns: Empirical evidence. The Journal of Finance, 43(2), 507-528.

Bou, J. C., \& Satorra, A. (2007). The persistence of abnormal returns at industry and firm levels: Evidence from Spain. Strategic Management Journal, 28(7), 707-722.

Bradshaw, M. T., Richardson, S. A., \& Sloan, R. G. (2006). The relation between corporate financing activities, analysts' forecasts and stock returns. Journal of Accounting and Economics, 42(1), 53-85.

Cai, J., \& Zhang, Z. (2011). Leverage change, debt overhang, and stock prices. Journal of Corporate Finance, 17(3), 391-402. 
De Roon, F., \& Veld, C. (1998). Announcement effects of convertible bond loans and warrant-bond loans: An empirical analysis for the Dutch market. Journal of Banking $\mathcal{E}$ Finance, 22(12), 1481-1506.

Dichev, I. D., \& Piotroskiapitaliza, J. D. (1999). The performance of long円run stock returns following issues of public and private debt. Journal of Business Finance $\mathcal{E}$ Accounting, 26(9-10), 1103-1132.

Dimitrov, V., \& Jain, P. C. (2006). The value relevance of changes in financial leverage. Available at SSRN 708281.

Eckbo, B. E. (1986). Valuation effects of corporate debt offerings. Journal of Financial economics, 15(1-2), 119-151.

Fama, E. F., \& French, K. R. (1992). The cross』section of expected stock returns. The Journal of Finance, $47(2), 427-465$.

Goddard, J., Tavakoli, M., \& Wilson, J. O. (2009). Sources of variation in firm profitability and growth. Journal of Business Research, 62(4), 495-508.

Ho, R. Y. W., Strange, R., \& Piesse, J. (2006). On the conditional pricing effects of beta, size, and bookto-market equity in the Hong Kong market. Journal of International Financial Markets, Institutions and Money, 16(3), 199-214.

Ho, R. Y. W., Strange, R., \& Piesse, J. (2008). Corporate financial leverage and asset pricing in the Hong Kong market. International Business Review, 17(1), 1-7.

Ho, K. Y., \& Abhyankar, A. (2002). Long-run abnormal performance following convertible security issues: New evidence from the UK. Available at SSRN 302142.

Hull, R. M., \& Moellenberndt, R. (1994). Bank debt reduction announcements and negative signaling. Financial Management, 21-30.

Khan, A. G. (2012). The relationship of capital structure decisions with firm performance: A study of the engineering sector of Pakistan. International Journal of Accounting and Financial Reporting, 2(1), 245-262.

Koop, G. (2005). Analysis of financial data (2nd ed.). England: John Wiley \& Sons.

Mason, R. D., Lind, D. A., \& Marchal, W. G. (1999). Statistical Techniques in Business and Economics (10 Ed.) McGraw-Hill

Mikkelson, W. H., \& Partch, M. M. (1986). Valuation effects of security offerings and the issuance process. Journal of Financial Economics, 15(1), 31-60.

Modigliani, F., \& Miller, M. H. (1958). The cost of capital, corporation finance and the theory of investment. The American Economic Review, 48(3), 261-297.

Myers, S. C. (1984). The capital structure puzzle. The Journal of Finance, 39(3), 574-592.

Myers, S. C., \& Majluf, N. S. (1984). Corporate financing and investment decisions when firms have information that investors do not have. Journal of financial economics, 13(2), 187-221. 
Rafique, M. (2011). Effect of profitability \& financial leverage on capital structure: A case of Pakistan's automobile industry. Available at SSRN 1911395.

Saeed, R. B. A., \& Badar, R. (2013). Impact of capital structure on performance empirical evidence from sugar sector of Pakistan. European Journal of Business and Management, 5(5), 78-86.

Shah, S. A. (2007). Corporate debt policy-pre-and post-financial market reforms: The case of the textile Industry of Pakistan. The Pakistan Development Review, 465-478.

Simerly, R. L., \& Li, M. (2000). Environmental dynamism, capital structure and performance: a theoretical integration and an empirical test. Strategic Management Journal, 21(1), 31-49.

Zeitun, R., \& Tian, G. G. (2007). Capital structure and corporate performance: Evidence from Jordan. Australasian Accounting Business and Finance Journal, 1(4), 40-61. 